\title{
The Isolation and Characterization of Glutamicibacter DC1 to Induce Carbonate Precipitation of Some Heavy Metals at Low-Temperature
}

\author{
Mingtang Li ${ }^{1}$, Hoaithuong Do ${ }^{1}$, Yihang Ding ${ }^{1}$, Yuqi Wang1, Chunli Zhao ${ }^{2 *}$, \\ Di Wu ${ }^{1}$, Chunyan Zhang ${ }^{1}$ \\ ${ }^{1}$ College of Resource and Environment, Jilin Agricultural University, Changchun 130118, China \\ ${ }^{2}$ College of Horticulture, Jilin Agricultural University, Changchun 130118, China
}

Received: 6 July 2021

Accepted: 27 September 2021

\begin{abstract}
The psychrotolerant bacteria able to induce carbonate precipitation of heavy metals at low temperatures play an essential role in the remediation of heavy metal contaminated soil in cold regions. In this study, a psychrotolerant bacterial strain DC1 with carbonate mineralization potential, identified as Glutamicibacter sp., was isolated from tailing soil. The optimal temperatures and $\mathrm{pH}$ range for the growth of strain $\mathrm{DC} 1$ were $10-30^{\circ} \mathrm{C}$ and $6-8$, respectively. Besides, strain DC1 showed a high degree of resistance to various metals $(\mathrm{Pb}>\mathrm{Cu}>\mathrm{Ni}>\mathrm{Cd})$. Furthermore, strain $\mathrm{DC} 1$ produced a large amount of urease $(266.91 \mathrm{U} / \mathrm{mL})$, which induced the fermentation suspension's $\mathrm{pH}\left(\mathrm{pH} 9.5\right.$ at $\left.10^{\circ} \mathrm{C}\right)$. Moreover, the fermentation suspension of strain $\mathrm{DCl}$ could generate carbonate precipitates of various metals $(\mathrm{Pb}$, $\mathrm{Cd}, \mathrm{Ni}$, and $\mathrm{Cu}$ ) to remove them from the solutions. Based on the analyses of XRD, SEM, and EDS, the carbonate precipitates of $\mathrm{Pb}$ and $\mathrm{Cd}$ have been identified as $\mathrm{PbCO}_{3}$ and $\mathrm{CdCO}_{3}$ mineral crystals, respectively. In contrast, no mineral crystals of $\mathrm{Ni}$ and $\mathrm{Cu}$ existed. Furthermore, the carbonate minerals of $\mathrm{Cd}$ and $\mathrm{Pb}$ with regular crystal improved resistance to dilute acid. Thus, this study showed that strain $\mathrm{DCl}$ without acid production could induce carbonate precipitates of $\mathrm{Pb}, \mathrm{Cd}, \mathrm{Cu}$, and $\mathrm{Ni}$ at lowtemperature.
\end{abstract}

Keywords: psychrotolerant bacterium, Glutamicibacter sp., microbially induced carbonate precipitate, heavy metals 


\section{Introduction}

In recent years, with economic and social development, heavy metals have been released into the environment in many ways and caused series of pollutions [1]. Arable soil pollution caused by coexisting heavy metals has attracted the researcher's attention because of its difficulty in remediation for safe farming [2, 3]. Heavy metal-polluted soil is currently remediated through physical, chemical, and biological methods [4-6]. The physicochemical process has many disadvantages, such as high cost, secondary pollution, which affect soil production function [7]. Hence, it was not suitable for the remediation of arable soil. The biological method based on microbial growth and metabolism is attracting more and more attention in the remediation of heavy metal contaminated arable soil due to its advantages, such as low cost and eco-friendliness $[8,9]$. Among the microorganisms used for remediation of heavy metal polluted soil, the one with the capacity to immobilize heavy metal ions by hydrolyzing urea to induce carbonate precipitate are becoming the researcher's targets. For example, Kocuria flava sp. and Sporosarcina koreensis sp. were reported to be involved in high urease production and high removal efficiency of $\mathrm{Cu}[10,11]$; Lysinibacillus sphaericus sp. was found with the feasibility of $\mathrm{Cd}$ bioremediation via carbonate precipitation [12], and Bacillus cereus sp. was used to remediate $\mathrm{Cr}$ in contaminated soil by inducing stable carbonate mineral [13]. However, most studies on heavy metal remediation by microbially induced carbonate precipitation are focused on individual heavy metal remediation. At the same time, there is a lack of microorganisms that can simultaneously immobilize various or co-existing heavy metals. Kang and So [14] have reported that the mix of multiple bacteria could remove $\mathrm{Pb}, \mathrm{Cd}$, and $\mathrm{Cu}$ mixture contaminated soils via microbially induced carbonate precipitation. Thus, this kind of microorganisms may have significant application significance in the remediation of heavy metals contaminated arable soil.

The remediation of heavy metal polluted arable soil is generally carried out before planting or after harvest. However, in areas with a long period of low temperatures, such as northeast China where the annual temperature during the year is no more than $15^{\circ} \mathrm{C}$, the microorganisms used for soil remediation should adapt to the low-temperature environment. Unfortunately, most of the microorganisms used for remediation of heavy metal polluted soil are mesophilic, and most of the researches has been carried out under temperature conditions of over $20^{\circ} \mathrm{C}[10,12,14]$. Temperature is one factor that affects the growth and metabolism of microorganisms [15]. As far as we know, there is a kind of psychrotolerant bacteria that can grow at low-temperature and assure their metabolisms in a cold region [16]. These psychrotolerant bacteria may play a vital role in the remediation of heavy metals contaminated soil in the cold environment.
For example, Kumari et al. [13] found that a psychrotolerant Exiguobacterium undae YR10 strain could immobilize $\mathrm{Cd}$ in soil by biomineralization at $10^{\circ} \mathrm{C}$. However, the knowledge of the psychrotolerant bacteria and their metabolism for heavy metal carbonate precipitation is unclear.

Therefore, we carried out the following research to provide highly efficient bacteria for remediation of arable soil polluted by various heavy metals. Firstly, we isolated and characterized the psychrotolerant bacteria that hydrolyzed urea and resisted different heavy metals at low temperatures. Then, the removal of heavy metals in solution by the psychrotolerant bacterium through inducing carbonate precipitation was studied. Also, the characteristics of carbonate precipitates were analyzed. Finally, the resistance of these carbonate precipitates to a weak acid solution was conducted. The current research would provide the theoretical basis for remediation of arable soil polluted by various heavy metals in a cold region.

\section{Materials and Methods}

\section{Isolation of Psychrotolerant Bacteria}

The soil sample in this study was collected from the Hongqiling tailings area of Jilin Province, China

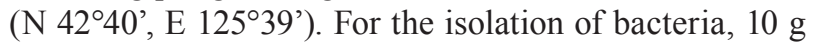
of the soil sample was added in $90 \mathrm{~mL}$ of sterile water sterilized and incubated at $10^{\circ} \mathrm{C}$ for $30 \mathrm{~min}$ in a shaker incubator $(160 \mathrm{rpm})$. Then, $1 \mathrm{~mL}$ of the suspension was diluted with the concentration gradients of $10^{-5}, 10^{-6}$, and $10^{-7}$ to prepare for separating the bacterial colony in a nutrient agar medium. These nutrient agar plates were incubated at $10^{\circ} \mathrm{C}$ for $5 \mathrm{~d}$ in an incubator. Each purified colony that grew in the plates was transferred to the urea agar plate (described by Alizadeh et al. [17]) for urease determination. Next, the colonies with positive urease were collected and incubated into nutrient broth (NB) medium (containing $3 \mathrm{~g} / \mathrm{L}$ of beef extract, $5 \mathrm{~g} / \mathrm{L}$ of peptone, $5 \mathrm{~g} / \mathrm{L}$ of sodium chloride with $\mathrm{pH} 7.0-7.2$ ) at $10^{\circ} \mathrm{C}, 160 \mathrm{rpm}$ for $48 \mathrm{~h}$. After that, the bacterial fermentation suspensions were centrifuged at $8000 \mathrm{rpm}\left(4^{\circ} \mathrm{C}\right)$ to collect the bacterial cells. These bacterial cells were diluted with sterile water until $\mathrm{OD}_{600}$ of $0.3\left(2.0 \times 10^{8} \mathrm{CFU} / \mathrm{mL}\right)$ as a bacterial suspension for the following experiments.

To observe the growth and urease activity of these selected bacterial strains, the bacterial suspensions $(2 \%$ of volume) were incubated in $200 \mathrm{~mL}$ of nutrient brothurea (NBU) medium (containing $3 \mathrm{~g} / \mathrm{L}$ of beef extract, $5 \mathrm{~g} / \mathrm{L}$ of peptone, $5 \mathrm{~g} / \mathrm{L}$ of sodium chloride, and $15 \mathrm{~g} / \mathrm{L}$ urea with $\mathrm{pH}$ of $7.0-7.2$ ) at $10^{\circ} \mathrm{C}, 160 \mathrm{rpm}$ for $54 \mathrm{~h}$. Then, at designated intervals (every $6 \mathrm{~h}$ for $54 \mathrm{~h}$ ), the $\mathrm{OD}_{600}, \mathrm{pH}$, and urease activity of the selected bacterial strains were determined. 
The Resistance of Isolated Psychrotolerant Bacteria to Heavy Metals Assay

One strain with high growth ability and high urease production was selected for the study of heavy metals resistances from the isolated bacterial strains. Based on the preliminary experiments of heavy metal resistance, we conducted the concentration of heavy metals as $\mathrm{Cd}(\mathrm{II})$ concentrations $(0-30 \mathrm{mg} / \mathrm{L}), \mathrm{Pb}(\mathrm{II})$ concentrations $(0-600 \mathrm{mg} / \mathrm{L}), \mathrm{Cu}(\mathrm{II})$ concentrations (0-130 mg/L), and $\mathrm{Ni}(\mathrm{II})$ concentrations $(0-120 \mathrm{mg} / \mathrm{L})$. The bacterial cell suspension with a volume ratio of $2 \%$ was inoculated in $200 \mathrm{~mL}$ of NBU medium and incubated at $10^{\circ} \mathrm{C}, 160 \mathrm{rpm}$ for $48 \mathrm{~h}$. The $\mathrm{OD}_{600}$ of the bacterial fermentation suspension was measured at a regular interval time.

\section{Identification of Psychrotolerant Bacteria}

The bacterial genomic DNA was extracted from the bacterial cells suspended in sterilized water and boiled at $100^{\circ} \mathrm{C}$ for $5 \mathrm{~min}$. The $16 \mathrm{~S}$ rRNA genes were amplified by polymerase chain reaction (PCR) protocol with universal primers, 27f (5'-AGAGTTTGATCCTGGCTCAG-3') and $1492 \mathrm{r}$ (5'-GGTTACCTTGTTACGACTT-3') as described in Al-Dhabaan [18]. Then, purified PCR products were sequenced directly and compared to the GenBank database using the Basic Local Alignment Search Tool (BLAST). Nucleotide sequences were aligned and matched with 16S rRNA, deposited in the NCBI GenBank under accession number MN659446.1 (Glutamicibacter sp. strain DC1). A phylogenetic tree was generated using the Neighbour-Joining method in MEGA version 7.0 software [19]. The obtained 16S rDNA sequences. Besides, the partial morphological, physiological, and biochemical properties of strain DC1 were analyzed.

\section{The Bacterial Growth and $\mathrm{pH}$ Variation Assay}

The bacterial cell suspension ( $2 \%$ of volume ratio) was inoculated in $200 \mathrm{~mL}$ of NBU medium with the initial $\mathrm{pH}$ of $5,6,7,8$, and 9 , respectively, and incubated at $10^{\circ} \mathrm{C}, 160 \mathrm{rpm}$ for $48 \mathrm{~h}$. Then, at a regular interval time (every $6 \mathrm{~h}$ for $48 \mathrm{~h}$ ), the $\mathrm{OD}_{600}$ and $\mathrm{pH}$ were determined to observe the bacterial growth and alkali production and/or change of $\mathrm{pH}$.

\section{Characterization of Heavy Metals Carbonate Precipitates Induced by Strain DC1}

In this experiment, the bacterial cell suspension ( $2 \%$ of volume ratio) was inoculated and incubated in $200 \mathrm{~mL}$ of NBU medium at $10^{\circ} \mathrm{C}, 160 \mathrm{rpm}$ for $48 \mathrm{~h}$ to collect the bacterial fermentation suspension. Then, $5 \mathrm{~mL}$ of $0.5 \mathrm{~mol} / \mathrm{L} \mathrm{CdCl}_{2} 10 \mathrm{~mL}$ of $0.5 \mathrm{~mol} / \mathrm{L} \mathrm{PbNO}_{3}$ $10 \mathrm{~mL}$ of $0.5 \mathrm{~mol} / \mathrm{L} \mathrm{NiCl}_{2}$ and $10 \mathrm{~mL}$ of $0.5 \mathrm{~mol} / \mathrm{L}^{2}$ $\mathrm{CuCl}_{2}$ were added in $200 \mathrm{~mL}$ of bacterial fermentation suspension, respectively, and stored at $10^{\circ} \mathrm{C}$ for 24 h. Afterward, the suspension liquids were collected to determine the heavy metal concentrations that remained in the solution. The precipitates obtained from the bottom of the flasks were dried at $50^{\circ} \mathrm{C}$ for $24 \mathrm{~h}$. The characteristics of the precipitates were analyzed using X-ray diffraction (XRD), scanning electron microscope (SEM), and energy spectrum (EDS).

\section{Stability of Mineralization Products in Acid Solution Assay}

The dried precipitates collected from section 2.4 were used in this experiment. The $0.5 \mathrm{~mol} / \mathrm{L}$ hydrochloric acid $(\mathrm{HCl})$ was used to adjust the $\mathrm{pH}$ of 5.0 as the acid solution in this experiment. First, $0.2 \mathrm{~g}$ of four precipitate products were added into $100 \mathrm{~mL}$ of the acid solution ( $\mathrm{pH}$ 5.0), respectively, in a shaker $\left(160 \mathrm{rpm}, 10^{\circ} \mathrm{C}\right)$ for $5 \mathrm{~h}$. Then, the supernatants were filtered through a $0.45 \mu \mathrm{m}$ membrane, and the concentration of heavy metals $(\mathrm{Cu}, \mathrm{Pb}, \mathrm{Cd}$, and $\mathrm{Ni})$ were measured, respectively.

The dissolution percentage of the heavy metals contained in precipitate products in acid solution was calculated as the followed equation:

$$
\text { Dissolution rate }(\%)=\left(C_{0} \times m\right) /\left(C_{t} \times V\right) \times 100
$$

Where $C_{0}(\mathrm{mg} / \mathrm{g})$ represents the content of heavy metals in the precipitate products, $m(\mathrm{~g})$ represents the mass of precipitate products, $C_{t}(\mathrm{mg} / \mathrm{L})$ represents the concentration of heavy metals in the acid solution after $5 \mathrm{~h}$, and $V(\mathrm{~L})$ represents the volume of the acid solution.

All the experiments were carried out with three replicates.

\section{Analytical Methods}

The urease activity was determined according to the phenol-hypochlorite assay method by Achal and Pan [2]. The optical density of the color complex was measured at $630 \mathrm{~nm}$ (Spectrophotometer, Spectrum Shanghai 722E, China) against the blank (1 mL phenol nitroprusside sodium $+1 \mathrm{~mL}$ sodium hypochlorite + distilled water). Ammonium chloride $(50-1,000 \mu \mathrm{M})$ was used as the standard. One unit of urease is defined as the amount of enzyme hydrolyzing $(1 \mu$ mole urea/ $\min$ ).

After filtered, heavy metal concentrations were analyzed using Graphite Furnace Atomic Absorption Spectrometry (GFAAS) (SP-3590AA, Shanghai, China). The heavy metals removal rate was calculated based on the following equation:

$$
\text { Removal efficiency }(\%)=\left(C_{0}-C\right) / C_{0} \times 100
$$

Where $\mathrm{C}_{0}$ and $\mathrm{C}_{t}$ are the concentration at initial and at time $\mathrm{t}$ of heavy metals ions $(\mathrm{mg} / \mathrm{L})$. 
The dried precipitates (section 2.4) were examined using the SEM-EDS system (X-550, SHIMADZU, Japan), according to Zhao et al. [20]. Also, the XRD was used to identify the characteristic of these precipitates described by Zhao et al. [20]. Furthermore, the heavy metals precipitates were compared with the International Centre for Diffraction Data (ICDD) mineral crystal database to identify their formula.

\section{Statistical Analyses}

The data were analyzed by analysis of variance (ANOVA), and the means were compared by Duncan's test $(p<0.05)$ using SPSS software (version 25.0). Error bars on graphs show the standard deviations of measurements. All the graphs were plotted by using Excel software 2013. In addition, the XRD patterns were analyzed using Jade5 software.

\section{Results and Discussion}

\section{Isolation of Psychrotolerant Bacteria}

Six bacterial strains with positive urease activity were isolated from the tailings area. These bacterial strains determined their growth and production abilities under low-temperature conditions (data not shown). The bacterial strain $\mathrm{DCl}$, which showed the best production rate of alkaline, and urease (Fig. 1), was selected for further study. The strain DC1 grew slowly in the first $8 \mathrm{~h}$, then increased rapidly from 8 to $48 \mathrm{~h}$, and reached the maximum growth value of 1.521 at $48 \mathrm{~h}$ under the temperature of $10^{\circ} \mathrm{C}$ (Fig. 1a). After that, the growth of the strain was relatively stable. This indicated that this bacterial strain might be psychrotolerant due to its characteristics similar to psychrotolerant bacteria [16].

During the bacterial growth, the $\mathrm{pH}$ of the fermentation suspension increased quickly in the first $48 \mathrm{~h}$, then gradually increased and reached a maximum value of 9.56 at $56 \mathrm{~h}$ (Fig. 1b). Afterward, the $\mathrm{pH}$ of the fermentation suspension seemed no change. There is an observation that the production of urease increased during the enhancement of bacterial growth. The maximum value of urease activity was $266.91 \mathrm{U} / \mathrm{mL}$ at $48 \mathrm{~h}$, and then it was stable during the stationary phase of bacterial growth (Fig. 1c). These phenomenons were similar to some previous studies, which reported the bacterial mechanism of urea hydrolysis [14, 21, 22]. The increase of $\mathrm{pH}$ and urease production indicated that strain DC1 would have the ability to induce carbonate precipitation $[23,24]$.

\section{The Growth of Strain DC1 in Different Levels of Heavy Metals}

The strain DC1 was tested with the resistance to some common heavy metals $(\mathrm{Cd}, \mathrm{Pb}, \mathrm{Cu}$, and $\mathrm{Ni})$. The results showed that in the stress conditions of different heavy metals, the strain DC1 could grow in a diverse range of heavy metals concentrations (Fig. 2). The highest concentration for $\mathrm{CD} 1$ growth was found to $\mathrm{Pb}$, with the concentration up to $550 \mathrm{mg} / \mathrm{L}$. On the other hand, the lower concentration for its development was observed with $\mathrm{Cu}$ concentration (up to $130 \mathrm{mg} / \mathrm{L}$ ) and $\mathrm{Ni}$ concentration $(120 \mathrm{mg} / \mathrm{L})$, while strain DC1 could grow in the medium with low Cd content $(20 \mathrm{mg} / \mathrm{L})$.

This strain showed the resistance to various heavy metals at different levels of concentrations. The minimum inhibitory concentrations of $\mathrm{Cd}, \mathrm{Pb}, \mathrm{Cu}$, and $\mathrm{Ni}$ by strain $\mathrm{DC} 1$ at $10^{\circ} \mathrm{C}$ were $20,550,130$, and $120 \mathrm{mg} / \mathrm{L}$, respectively. This difference in resistance of strain DC1 to various heavy metals might be because of the adaptation of strain DC1 to different pollution areas with elevated heavy metal levels. Gadd [25] demonstrated that microbial cells grown at high metal concentrations had been related to the bacterial mechanisms of resistance and environmental factors. Moreover, heavy metal-resistant bacteria have been reported to participate in heavy metal remediation in contaminated environments $[14,26]$. Therefore, our results showed that strain DC1 would potentially immobilize heavy metals in a cold environment. a)

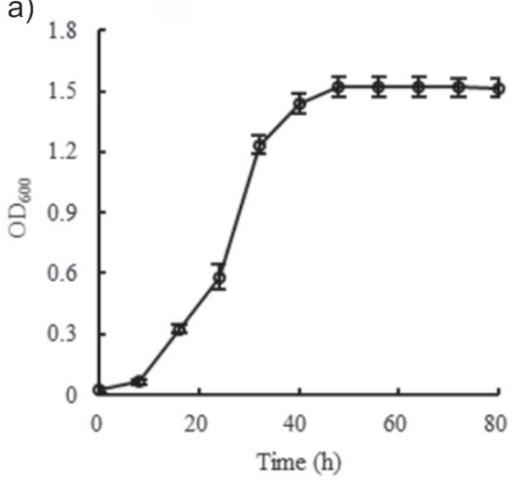

b)

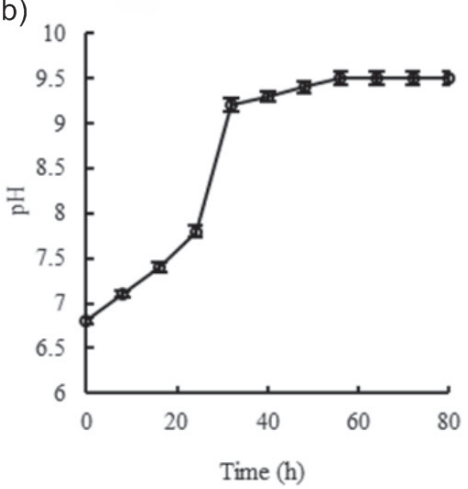

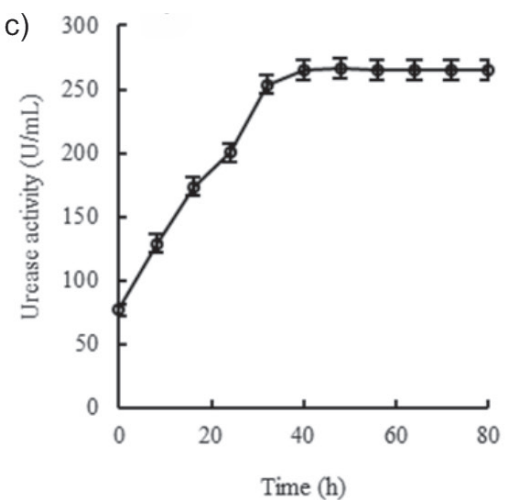

Fig. 1. The bacterial growth a), the change of fermentation suspension $\mathrm{pH}$ b), and the urease activity c) of strain DC1 after $80 \mathrm{~h}$ of incubation. Each value is the mean of triplicates. Error bars represent standard deviation. 

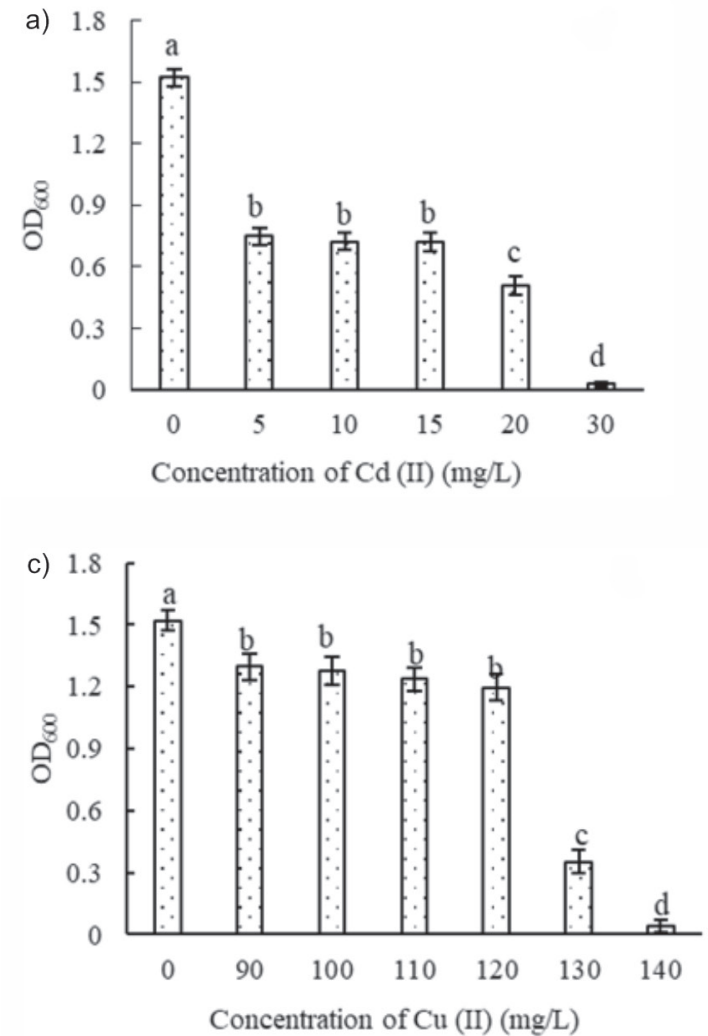
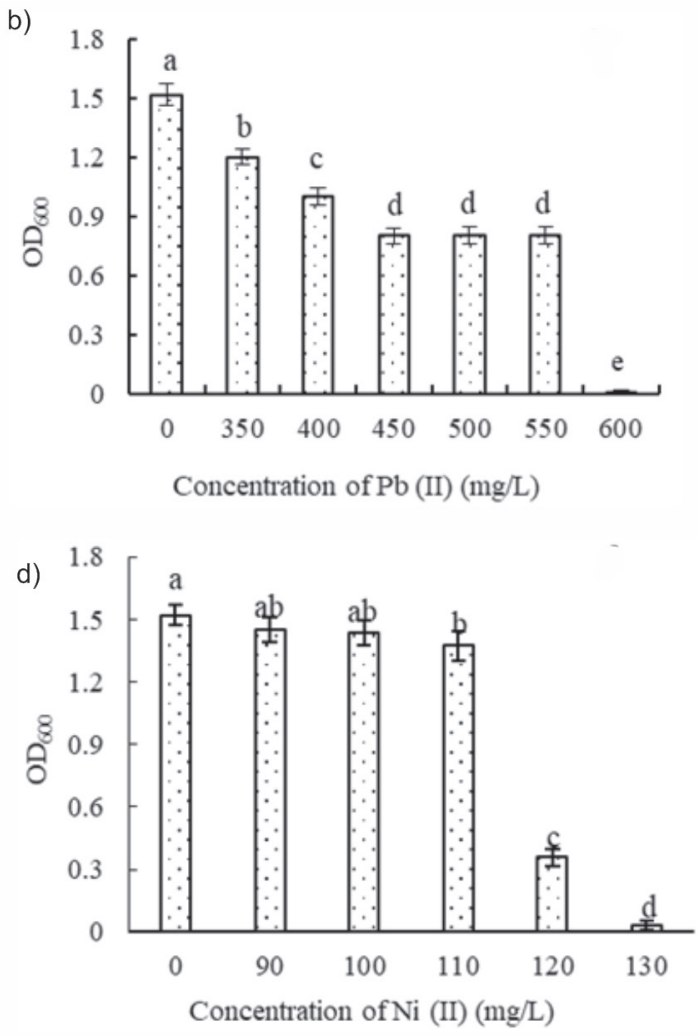

Fig. 2. The growth of strain DC1 in different levels of heavy metals a) $\mathrm{Cd}$ (II), b) $\mathrm{Pb}$ (II), c) $\mathrm{Cu}$ (II), d) $\mathrm{Ni}$ (II). Each value is the mean of triplicates. Error bars represent standard deviation. The letters a, b, c, etc. represent the significant difference between treatments based on Duncan's test result $(\mathrm{p}<0.05)$.

\section{Identification of Strain DC1}

Strain DC1 was identified based on colony characteristics, cell morphology, gram staining, and 16S rDNA gene sequence analyses. The results showed that the surface of the strain DC1 was wet, smooth, and yellow opaque on the NB medium. Strain DC1 is a Gram-positive with short and small rod cells. Also, it could utilize glucose to grow but not to produce acid. Besides, the phylogenetic analysis based on $16 \mathrm{~S}$ rDNA sequences showed that DC1 was homologous to Paeniglutamicibacter psychrophenolicus AG31 (Gene bank: NR 027226.1) and Glutamicibacter soli SYB2 (Gene bank: NR 044338.1) (Fig. 3). Therefore, strain DC1 was identified as belonging to the Glutamicibacter genus.

Strain DC1 could grow in glucose medium but could not assimilate glucose, which has rarely been found with Glutamicibacter strains since most of the tested strains utilized this carbon source [27]. This might be due to the adaptation of strain $\mathrm{DCl}$ in the environment containing harmful heavy metals. Also, the lack of acid production can reduce the heavy metal toxicity to limit the damages caused to the strain body. Besides, strain DC1 could hydrolyze urea to produce the urease enzyme. This result is similar to the previous study reported about Peaniglutamicibacter psychrophenolicus [28]. However, in this previous study, the authors demonstrated that $P$. psychrophenolicus sp. could grow in various temperatures $\left(1-25^{\circ} \mathrm{C}\right)$ and different $\mathrm{pH}$ (6-10) as the psychrotolerant bacteria [28]. Hence, strain DC1 would have the ability of a psychrotolerant strain to survive at low-temperature. Moreover, most of the studies on microorganisms that can induce carbonate mineralization by hydrolyzing urea were reported for Bacillus sp. [13, 29, 30], Sporosarcina ginsengisoli sp. [31], Lysinibacillus sphaericus sp. [12], Kocuria flava sp. [10]. While, the remediation ability of heavy metal by bacterial-induced carbonate mineralization using Glutamicibacter $\mathrm{sp}$. has been rarely reported, especially at low temperatures. Therefore, it is necessary to study the growth metabolism of strain $\mathrm{DCl}$ and its potential for heavy metal remediation under low-temperature conditions.

Effects of the Environmental Factors on the Growth of Strain DC1 and pH Change of the Fermentation Suspension

The growth of strain $\mathrm{DCl}$ and $\mathrm{pH}$ variation of the fermentation suspension at different temperatures (Fig. 4) revealed that strain $\mathrm{DCl}$ had the strongest growth with the $\mathrm{OD}_{600}$ value of 1.623 and the highest $\mathrm{pH}$ value $(9.5)$ at $25^{\circ} \mathrm{C}$. Besides, this strain showed good growth and raising $\mathrm{pH}$ under the temperature conditions from $10^{\circ} \mathrm{C}$ to $30^{\circ} \mathrm{C}$ (Fig. $4 \mathrm{a}$ and b) with no significant 


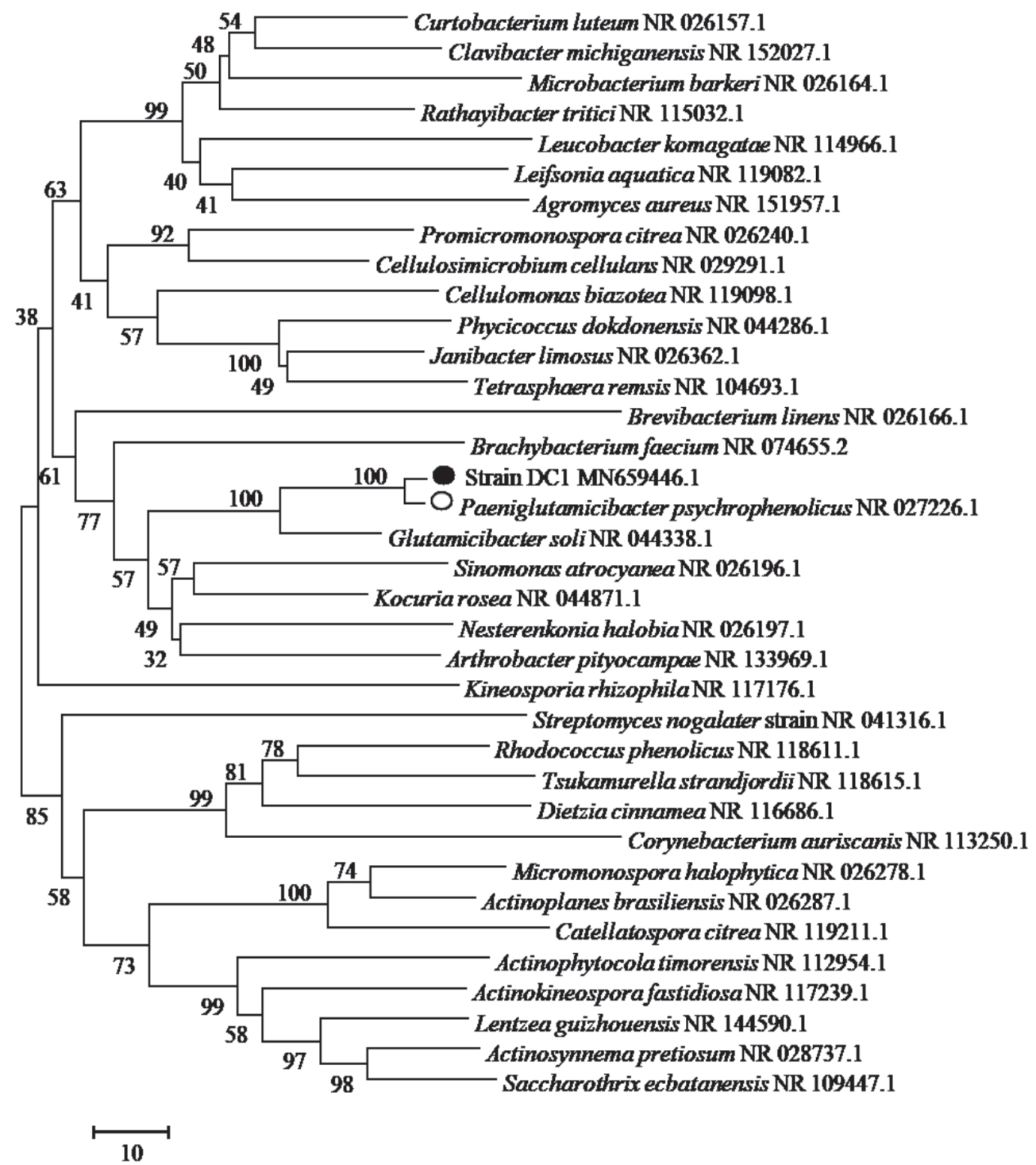

Fig. 3. Phylogenetic relationship based on 16S rRNA sequences of Glutamicibacter strain DC1 with available strains at Gen Bank. The numerical values at nodes are percentage bootstrap values based on 1000 replicates.

differences at 10,25 , and $30^{\circ} \mathrm{C}$ (Fig. 4b). However, at lower $\left(5^{\circ} \mathrm{C}\right)$ or higher $\left(35-40{ }^{\circ} \mathrm{C}\right)$ temperatures, the growth of strain DC1 was significantly affected, inducing the decrease in the $\mathrm{pH}$ of fermentation suspension (Fig. 4b). This showed that strain DC1 could grow in an extensive range of temperatures $\left(5-40^{\circ} \mathrm{C}\right)$, indicating the ability of a psychrotolerant bacterium [32].

Moreover, the initial $\mathrm{pH}$ of the solution also affected the growth of strain $\mathrm{DCl}$ and the change of $\mathrm{pH}$ of the fermentation suspension. The strain DC1 was observed with the most substantial growth capacity when the initials $\mathrm{pH}$ were 7 and 8 (Fig. 4c). With the lower initial $\mathrm{pH}$ of 5 or 6 , the bacterial growths were slowly in the first $72 \mathrm{~h}$, then reached the stable stage with similar values when the $\mathrm{pH}$ were 7 and 8 . The strain DC1 showed the weakest growth when the initial $\mathrm{pH}$ was 9, but after $96 \mathrm{~h}$, no significant difference in the bacterial growth was observed with another initial $\mathrm{pH}$. During bacterial growth, the $\mathrm{pH}$ of fermentation suspensions was changed in specific regular (Fig. 4d). With all the initials $\mathrm{pH}$, the final $\mathrm{pH}$ of fermentation suspension was going to 7.4-7.8.

These results indicated that the strain DC1 could apply for heavy metal remediation under the normal temperature condition and play a crucial role in the remediation of heavy metal polluted soil by inducing carbonate precipitation in the cold regions. Besides, the effect of initial $\mathrm{pH}$ on strain $\mathrm{DC} 1$ showed that the optimum $\mathrm{pH}$ for bacterial growth was 7-8, the optimum $\mathrm{pH}$ for most of the psychrotolerant bacteria growth [28, $32]$. We found that with a weak acid $(\mathrm{pH}=5-6)$ or weak alkaline $(\mathrm{pH}=9)$, the bacterial growth was slow, but it still could reach the maximum value after $120 \mathrm{~h}$, similar to the growth under 7 or 8 . This indicated that strain DC1 is strongly adapted to grow in low-temperature soil with an extensive $\mathrm{pH}$ range. 

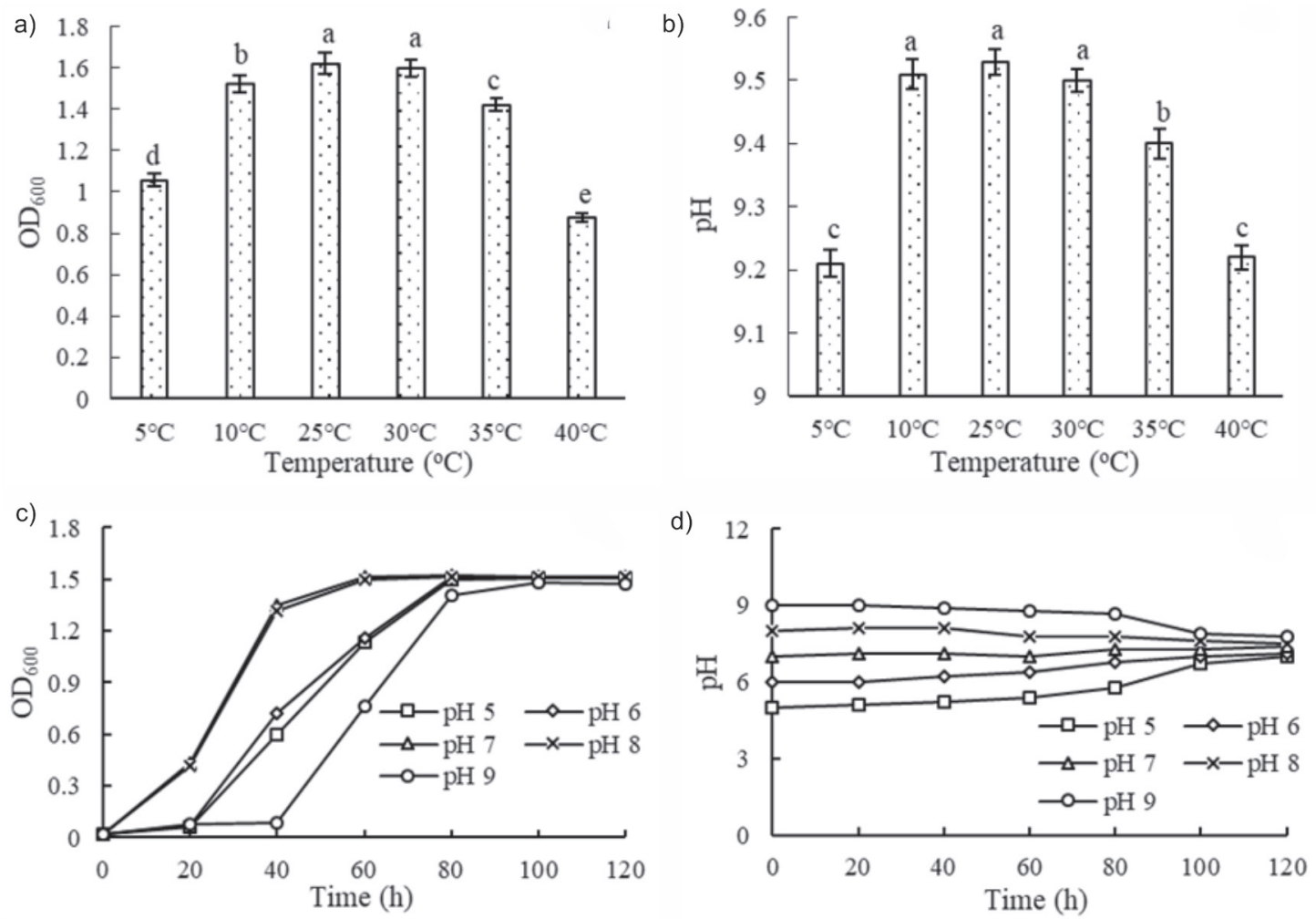

Fig. 4. The growth rate of strain DC1 under different temperatures a) and the influence of various temperatures on the change of $\mathrm{pH}$ in the fermentation suspension b). Effects of different initial $\mathrm{pH}$ on cell growth $\mathrm{c}$ ) and $\mathrm{pH}$ of fermentation suspension d). Each value is the mean of triplicates. Error bars represent standard deviation. The letters a, b, c, etc. represent the significantly different based on Duncan's test result $(\mathrm{p}<0.05)$.

\section{The Removal Efficiency of Heavy Metals in Fermentation Suspension at $10^{\circ} \mathrm{C}$}

Fig. 5 shows the removal efficiencies of four heavy metals $(\mathrm{Cd}, \mathrm{Pb}, \mathrm{Cu}$, and $\mathrm{Ni})$ in the fermentation suspensions. As can be seen, the highest removal efficiencies have been observed for $\mathrm{Cd}$ (II) and $\mathrm{Pb}$ (II), with values of $92.67 \%$ and $93.67 \%$, respectively. On the other hand, for $\mathrm{Cu}$ (II) and $\mathrm{Ni}$ (II), the removal

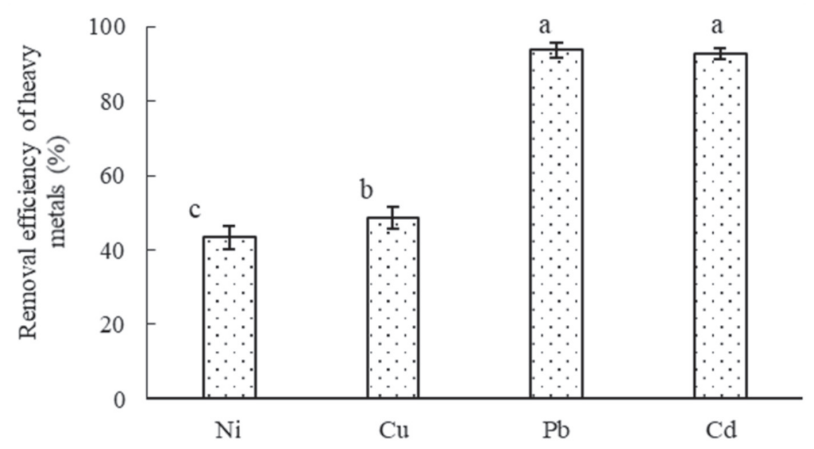

Fig. 5. The removal efficiencies of heavy metals in the fermentation suspension by strain DC1. Each value is the mean of triplicates. Error bars represent standard deviation. The letters $\mathrm{a}, \mathrm{b}$, and c represent the significantly different based on Duncan's test result $(\mathrm{p}<0.05)$. efficiencies were less than $50 \%$ (specifically, $48.67 \%$ of $\mathrm{Cu}$ (II) and $43.33 \%$ of $\mathrm{Ni}(\mathrm{II})$ ).

This could be explained by the different removal mechanisms of strain DC1 to various heavy metals. For example, the previous study of $\mathrm{Li}$ et al. [33] showed that the removal rates of $\mathrm{Pb}$ and $\mathrm{Cd}$ by $T$. tumescens $\mathrm{A} 12$ were significantly higher than the ones of $\mathrm{Cu}$ and $\mathrm{Ni}$, but all of them could be removed at more than $90 \%$. This contrasts with our results, which could be explained by the type of bacteria that have different metabolism for the removal of heavy metals. Also, the low-temperature condition might affect the removal rate of heavy metals by strain DC1. These results also indicated that strain DC1 could precipitate heavy metals in solution [33].

\section{Characteristics of the Heavy Metals Carbonate Precipitates}

The carbonate precipitates of four heavy metals $(\mathrm{Cd}$, $\mathrm{Pb}, \mathrm{Cu}$, and $\mathrm{Ni}$ ) were characterized using XRD, SEMEDS analyses (Fig. 6). The XRD pattern of $\mathrm{Cd}$ and $\mathrm{Pb}$ precipitates showed the peaks of $\mathrm{Cd}$ and $\mathrm{Pb}$ carbonate minerals, respectively (Fig. 6a and b). According to the PDF card database of Jade5 software, we found that they were $\mathrm{CdCO}_{3}$ (PDF 42-1342) and $\mathrm{PbCO}_{3}$ (PDF 47-1734). In comparison, there was no carbonate mineral structure formed in $\mathrm{Cu}$ and $\mathrm{Ni}$-containing precipitates (Fig. 6c and d). 
a)
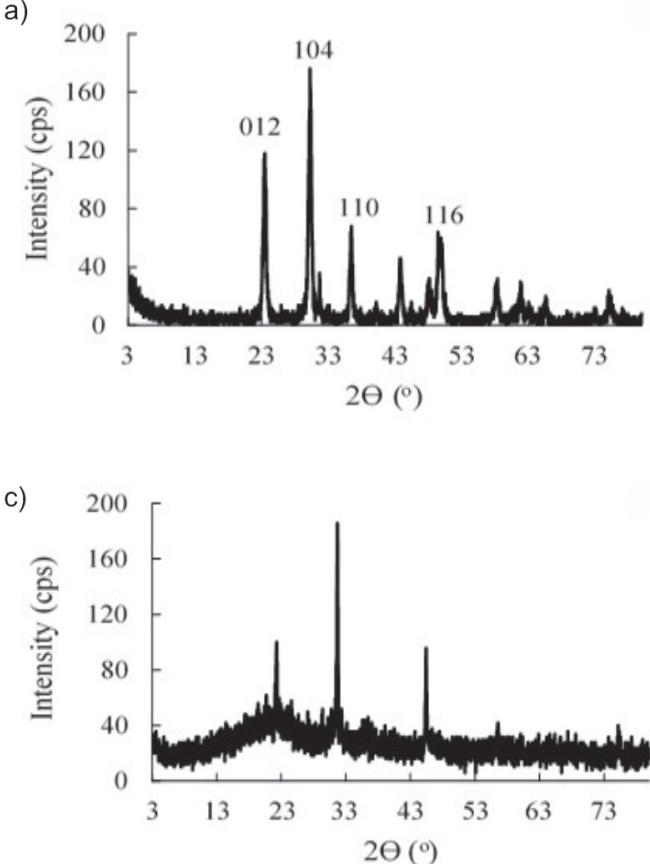

e)

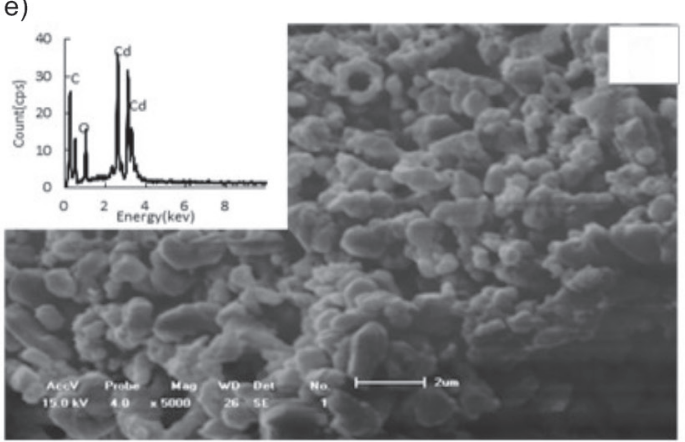

g)

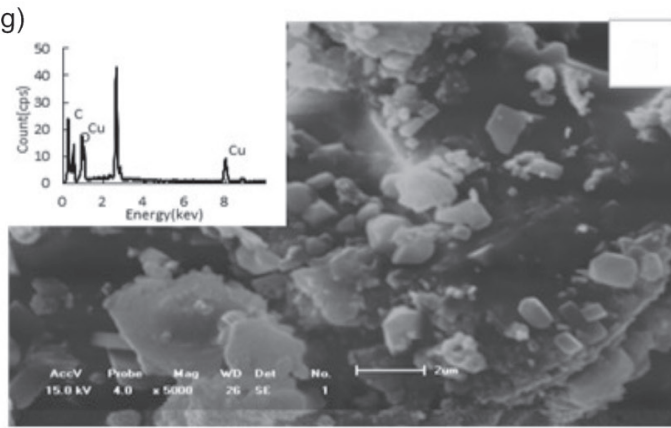

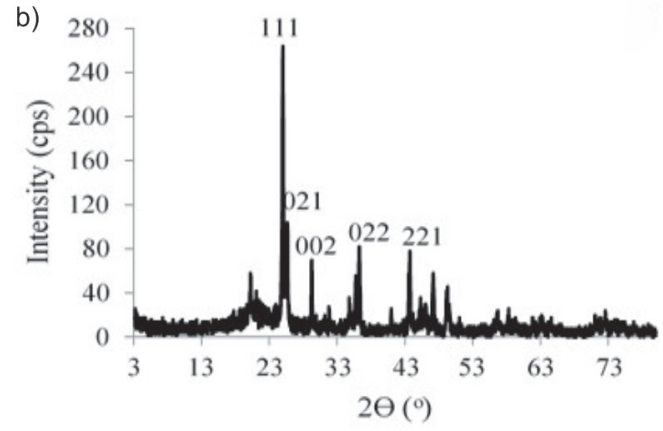

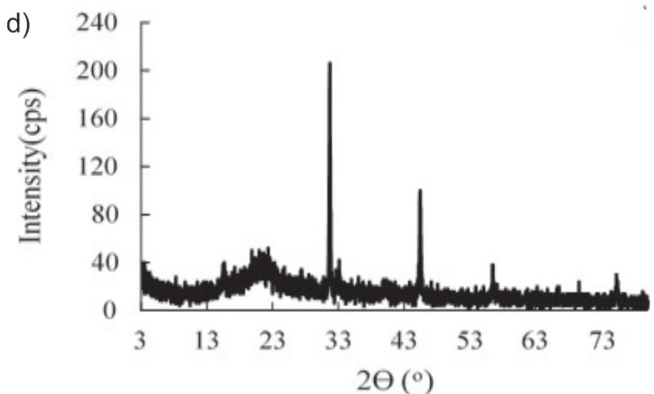

f)
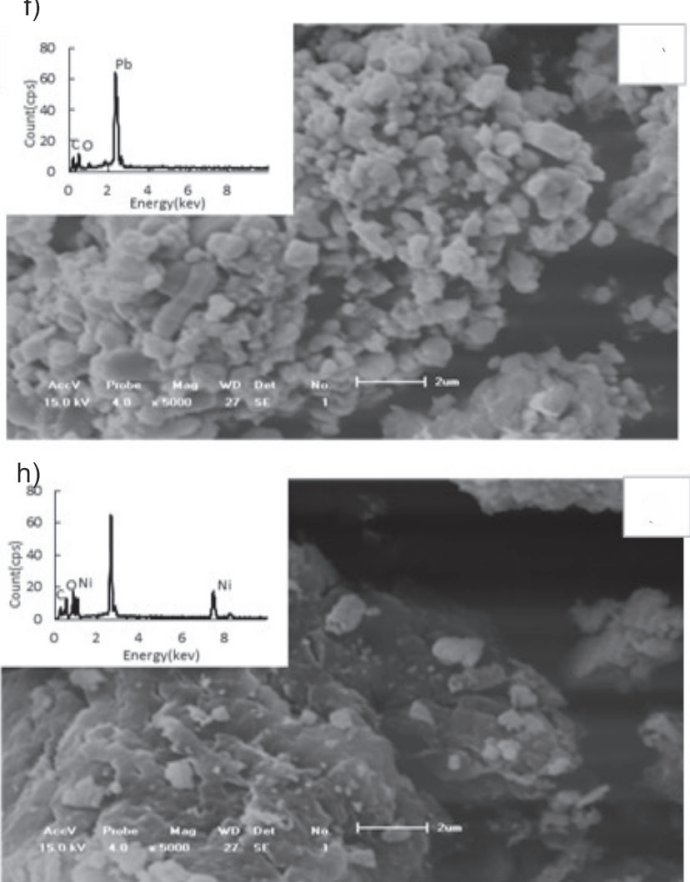

Fig. 6. The characteristics of heavy metals containing carbonate precipitates by strain DC1. The XRD patterns of carbonate precipitates of a) $\mathrm{Cd}$, b) $\mathrm{Pb}$, c) $\mathrm{Cu}$, d) $\mathrm{Ni}$; the SEM-EDS of carbonate precipitates of e) $\mathrm{Cd}, \mathrm{f}$ ) $\mathrm{Pb}, \mathrm{g}$ ) $\mathrm{Cu}, \mathrm{h}$ ) $\mathrm{Ni}$.

The morphological characteristics of four carbonate precipitates using SEM-EDS analyses showed that $\mathrm{Cd}$ and $\mathrm{Pb}$ carbonate precipitates were regular shapes with rhombohedra, spherical crystal (Fig. 6e), and small spherical, cube crystal (Fig. 6f), respectively. Besides, the EDS analysis showed that the carbonate precipitates of $\mathrm{Cd}$ and $\mathrm{Pb}$ mainly contain $\mathrm{C}, \mathrm{O}, \mathrm{Cd}$ elements (Fig. 6e) or $\mathrm{C}, \mathrm{O}$, and $\mathrm{Pb}$ elements (Fig. 6f), respectively, which further proven by the XRD results. However, the carbonate precipitates of $\mathrm{Cu}$ and $\mathrm{Ni}$ mainly contain $\mathrm{C}$, $\mathrm{O}$, and $\mathrm{Cu}$ elements or $\mathrm{C}, \mathrm{O}$, and $\mathrm{Ni}$ elements, respectively, but no regular crystal structure was found (Fig 6g, h).

These results were related to the removal rates, strain $\mathrm{DCl}$ absorbed more $\mathrm{Cd}$ (II) and $\mathrm{Pb}$ (II) to form the carbonate minerals, and the few amounts of $\mathrm{Cu}$ (II) and $\mathrm{Ni}$ (II) absorbed were not enough to create the stable mineral structure. In addition, most of the studies on $\mathrm{Cd}$ or $\mathrm{Pb}$ carbonate precipitate by ureolytic bacteria were reported with the regular mineral crystal of $\mathrm{CdCO}_{3}$ or $\mathrm{PbCO}_{3}[11-13,29,34,35]$. In this study, we found similar results that strain DC1 could induce 


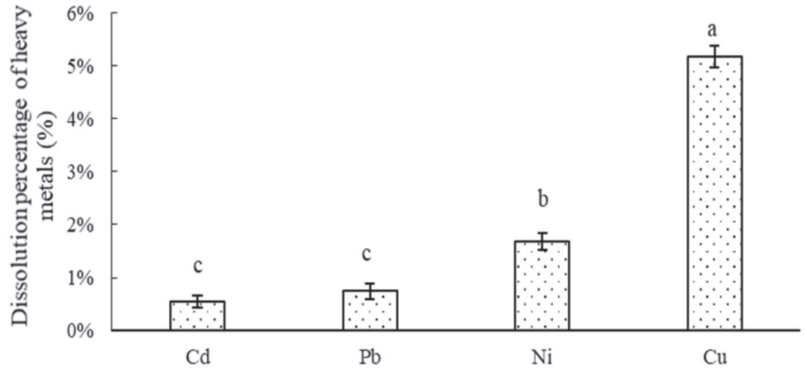

Fig. 7. The dissolution efficiencies of the heavy metals $(\mathrm{Cd}, \mathrm{Pb}$, $\mathrm{Ni}, \mathrm{Cu}$ ) containing precipitate products in acid solution. Each value is the mean of triplicates. Error bars represent standard deviation. The letters $\mathrm{a}, \mathrm{b}$, and $\mathrm{c}$ represent the significantly different based on Duncan's test result $(\mathrm{p}<0.05)$.

carbonate minerals of $\mathrm{Cd}$ and $\mathrm{Pb}$ with the rhombohedra and spherical crystal of $\mathrm{CdCO}_{3}$ and tiny spherical and cube crystals of $\mathrm{PbCO}_{3}$. This could be concluded that most of the ureolytic bacteria could form the carbonate minerals of $\mathrm{Cd}$ or $\mathrm{Pb}$, but the morphologies of mineral induced by different microorganisms were different [13; 33]. Moreover, the results of $\mathrm{Cu}$ and $\mathrm{Ni}$-carbonate precipitates showed the absence of formed mineral crystal, which is similar to Achal et al. [10], who demonstrated that Kocuria flava CR1 could remove the high efficiency of $\mathrm{Cu}$ from the solution, but no $\mathrm{Cu}$-crystal mineral was recorded. In opposition to this phenomenon, Li et al. [33] reported that T. tumescens A12 induced carbonate mineral precipitation of various heavy metals $(\mathrm{Ni}, \mathrm{Cu}, \mathrm{Co}, \mathrm{Pb} . .$.$) to remove these heavy$ metals from both liquid and porous media. Furthermore, Bacillus cereus NS4 was also found to reduce the soluble-exchangeable $\mathrm{Ni}$ from the soil and form stable mineral crustal of $\mathrm{NiCO}_{3}$ in remediated soil [30]. However, these above previous studies were conducted under the normal temperature of $27-30^{\circ} \mathrm{C}$, while our study was carried out at low temperature $\left(10^{\circ} \mathrm{C}\right)$, so the temperature might affect the bacterial metabolism and the formation of carbonate mineralization of $\mathrm{Cu}$ and $\mathrm{Ni}$.

\section{The Stability of Heavy Metals Precipitates in Acid Solution}

The stabilities of the four precipitate products in acid solution were expressed by the dissolution efficiencies of the heavy metals that existed in these products in the acid solution (Fig. 7). The results showed that $\mathrm{Cu}$-containing products had the highest dissolution efficiency (5.17\%) in acid solution. The second high dissolution efficiency with a value of $1.68 \%$ was found in the Ni-containing precipitate product. The precipitate products of $\mathrm{Cd}$ and $\mathrm{Pb}$ with the dissolution rate of $0.55 \%$ and $0.74 \%$ were the least dissolved in acid solution.

The carbonate precipitates of $\mathrm{Pb}, \mathrm{Cd}, \mathrm{Ni}$, and $\mathrm{Cu}$ showed different resistance levels to dilute acid. The carbonate precipitates of $\mathrm{Pb}$ and $\mathrm{Cd}$ with mineral crystal were more resistant to acid than that of $\mathrm{Ni}$ and
$\mathrm{Cu}$ in the non-mineral crystal structure. This indicates that the regular mineral crystal structure is helpful to improve the stability of carbonate precipitate induced by microorganisms. Therefore, strain $\mathrm{DCl}$ could be considered as an element for remediation of $\mathrm{Pb}$ and Cd polluted arable soil, even in areas with severe soil acidification under low-temperature conditions.

\section{Conclusion}

In conclusion, a psychrotolerant bacterium, identified as Glutamicibacter DC1, was isolated from the tailing area. Strain DC1 showed strong growth ability and high urease production at $10{ }^{\circ} \mathrm{C}$. Meanwhile, it could grow at high concentrations of $\mathrm{Pb}, \mathrm{Cd}, \mathrm{Ni}$, and $\mathrm{Cu}$ respectively. The fermentation suspension could remove most of the heavy metals, in the order of $\mathrm{Cd}, \mathrm{Pb}>\mathrm{Cu}>\mathrm{Ni}$, by inducing the formation of carbonate precipitates. The carbonate precipitates of $\mathrm{Cd}$ and $\mathrm{Pb}$ were the regular mineral crystals of $\mathrm{PbCO}_{3}$ and $\mathrm{CdCO}_{3}$. In contrast, the ones of $\mathrm{Cu}$ and $\mathrm{Ni}$ did not show any mineral crystals. Moreover, the carbonate precipitates of $\mathrm{Cd}$ and $\mathrm{Pb}$ were more resistant to the diluted acid solution than those of $\mathrm{Cu}$ and $\mathrm{Ni}$. For the environmental and agricultural practice, strain DC1 can be applied to the soil together with organic fertilizer or alone for the immobilization of $\mathrm{Pb}, \mathrm{Cd}, \mathrm{Cu}$, and $\mathrm{Ni}$.

In some cases, heavy metals are usually coexisting in soil. Besides, the growth of plants maybe affects the stability of carbonate precipitates of heavy metals. Therefore, our future research work will focus on the carbonate precipitation of co-existing $\mathrm{Pb}, \mathrm{Cd}$, $\mathrm{Cu}$, and Ni. Meanwhile, the effect of plant growth on the stability of carbonate minerals will be further studied.

\section{Acknowledgments}

This work was supported by the National Natural Science Foundation of China (41877136 and 42077137) and the Key Research and Development Program of Jilin province, China (20200403003SF).

\section{Conflict of Interest}

The authors declare no conflict of interest.

\section{References}

1. FAROUK S., MOSA A., TAHA A., EL-GAHMERY A. Protective effect of humic acid and chitosan on radish (Raphanus sativus, L. var. sativus) plants subjected to cadmium stress. Journal of Stress Physiology \& Biochemistry, 7 (2), 2011.

2. ACHAL V., PAN X. Characterization of urease and carbonic anhydrase producing bacteria and their role in 
calcite precipitation. Current microbiology, 62 (3), 894, 2011.

3. WANG X.Y. Characteristic and environmental risk assessment of heavy metals in farmland soil of based on speciation analysis. in: Informatics and Management Science I, Springer, 213, 2013.

4. ANDREAZZA R., PIENIZ S., OKEKE B.C., CAMARGO F.A.D.O. Evaluation of copper resistant bacteria from vineyard soils and mining waste for copper biosorption. Brazilian Journal of Microbiology, 42 (1), 66, 2011.

5. SIVAPATHAM P., LETTIMORE J.M., ALVA A.K., JAYARAMAN K., HARPER L.M. Chemical fractionation of $\mathrm{Cu}, \mathrm{Zn}, \mathrm{Cd}, \mathrm{Cr}$, and $\mathrm{Pb}$ in sewage sludge amended soils at the end of 65-d sorghum-sudan grass growth. Journal of Environmental Science and Health, Part A, 49 (11), 1304, 2014.

6. YAO Z., LI J., XIE H., YU C. Review on remediation technologies of soil contaminated by heavy metals. Procedia Environmental Sciences, 16, 722, 2012.

7. KHALID S., SHAHID M., NIAZI N.K., MURTAZA B., BIBI I., DUMAT C. A comparison of technologies for remediation of heavy metal contaminated soils. Journal of Geochemical Exploration, 182, 247, 2017.

8. MORGAN J., BENDING G., WHITE P. Biological costs and benefits to plant-microbe interactions in the rhizosphere. Journal of experimental botany, 56 (417), 1729, 2005

9. VANDECASTEELE B., SAMYN J., QUATAERT P., MUYS B., TACK F.M. Earthworm biomass as additional information for risk assessment of heavy metal biomagnification: a case study for dredged sedimentderived soils and polluted floodplain soils. Environmental Pollution, 129 (3), 363, 2004.

10. ACHAL V., PAN X., ZHANG D. Remediation of copper-contaminated soil by Kocuria flava CR1, based on microbially induced calcite precipitation. Ecological Engineering, 37 (10), 1601, 2011.

11. LI M., CHENG X., GUO H. Heavy metal removal by biomineralization of urease producing bacteria isolated from soil. International Biodeterioration \& Biodegradation, 76, 81, 2013.

12. KANG C.-H., HAN S.-H., SHIN Y., OH S.J., SO J.-S. Bioremediation of $\mathrm{Cd}$ by microbially induced calcite precipitation. Applied biochemistry and biotechnology, 172 (6), 2907, 2014.

13. KUMARI D., PAN X., LEE D.-J., ACHAL V. Immobilization of cadmium in soil by microbially induced carbonate precipitation with Exiguobacterium undae at low temperature. International Biodeterioration \& Biodegradation, 94, 98, 2014.

14. KANG C.-H., SO J.-S. Heavy metal and antibiotic resistance of ureolytic bacteria and their immobilization of heavy metals. Ecological Engineering, 97, 304, 2016.

15. MARGESIN R., SCHINNER F. Properties of cold-adapted microorganisms and their potential role in biotechnology. Journal of Biotechnology, 33 (1), 1, 1994.

16. MOYER C.L., MORITA R.Y. Psychrophiles and psychrotrophs. e LS, 2001.

17. ALIZADEH H., KANDULA D.R., HAMPTON J.G., STEWART A., LEUNG D.W., EDWARDS Y., SMITH C. Urease producing microorganisms under dairy pasture management in soils across New Zealand. Geoderma regional, 11, 78, 2017.

18. AL-DHABAAN F.A. Morphological, biochemical and molecular identification of petroleum hydrocarbons biodegradation bacteria isolated from oil polluted soil in Dhahran, Saud Arabia. Saudi Journal of Biological Sciences, 26 (6), 1247, 2019.

19. KUMAR S., STECHER G., TAMURA K. MEGA7: Molecular Evolutionary Genetics Analysis Version 7.0 for Bigger Datasets. Mol Biol Evol, 33 (7), 1870, 2016.

20. ZHAO X., DO H., ZHOU Y., LI Z., ZHANG X., ZHAO S., LI M., WU D. Rahnella sp. LRP3 induces phosphate precipitation of $\mathrm{Cu}$ (II) and its role in copper-contaminated soil remediation. Journal of hazardous materials, 368, 133, 2019.

21. BURBANK M.B., WEAVER T.J., WILLIAMS B.C., CRAWFORD R.L. Urease activity of ureolytic bacteria isolated from six soils in which calcite was precipitated by indigenous bacteria. Geomicrobiology Journal, 29 (4), 389, 2012.

22. KHADIM H.J., AMMAR S.H., EBRAHIM S.E. Biomineralization based remediation of cadmium and nickel contaminated wastewater by ureolytic bacteria isolated from barn horses soil. Environmental Technology \& Innovation, 14, 1, 2019

23. WONG L.S. Microbial cementation of ureolytic bacteria from the genus Bacillus: a review of the bacterial application on cement-based materials for cleaner production. Journal of Cleaner Production, 93, 5, 2015.

24. DO H., WANG Y., LONG Z., KETEHOULI T., LI X., ZHAO Z., LI M. A psychrotolerant Ni-resistant Bacillus cereus D2 induces carbonate precipitation of nickel at low temperature. Ecotoxicology and environmental safety, 198, 110672, 2020.

25. GADD G.M. Bioremedial potential of microbial mechanisms of metal mobilization and immobilization. Current opinion in biotechnology, 11 (3), 271, 2000.

26. GOVARTHANAN M., LEE K.-J., CHO M., KIM J.S., KAMALA-KANNAN S., OH B.-T. Significance of autochthonous Bacillus sp. KK1 on biomineralization of lead in mine tailings. Chemosphere, 90 (8), 2267, 2013.

27. BUSSE H.-J. Review of the taxonomy of the genus Arthrobacter, emendation of the genus Arthrobacter sensu lato, proposal to reclassify selected species of the genus Arthrobacter in the novel genera Glutamicibacter gen. nov., Paeniglutamicibacter gen. nov., Pseudoglutamicibacter gen. nov., Paenarthrobacter gen. nov. and Pseudarthrobacter gen. nov., and emended description of Arthrobacter roseus. International Journal of Systematic and Evolutionary Microbiology, 66 (1), 9, 2016.

28. MARGESIN R., SCHUMANN P., SPRÖER C., GOUNOT A.-M. Arthrobacter psychrophenolicus sp. nov., isolated from an alpine ice cave. International journal of systematic and evolutionary microbiology, 54 (6), 2067, 2004.

29. ZHAO Y., YAO J., YUAN Z., WANG T., ZHANG Y., WANG F. Bioremediation of Cd by strain GZ-22 isolated from mine soil based on biosorption and microbially induced carbonate precipitation. Environmental Science and Pollution Research, 24 (1), 372, 2017.

30. ZHU X., LI W., ZHAN L., HUANG M., ZHANG Q., ACHAL V. The large-scale process of microbial carbonate precipitation for nickel remediation from an industrial soil. Environ Pollut, 219, 149, 2016.

31. ACHAL V., PAN X., FU Q., ZHANG D. Biomineralization based remediation of As(III) contaminated soil by Sporosarcina ginsengisoli. Journal of Hazardous Materials, 201-202, 178, 2012.

LI M.T., LIU J.H., ZHAO S.J., WANG Z.X., HAO L.L. The characteristics of nitrate removal by the psychrotolerant denitrifying bacterium Acinetobacter 
johnonii DBP-3, isolated from a low-temperature eutrophic body of water. Journal of Environmental Science and Health, Part B, 48 (10), 885, 2013.

32. LI M., CHENG X., GUO H., YANG Z. Biomineralization of Carbonate by Terrabacter Tumescens for Heavy Metal Removal and Biogrouting Applications. Journal of Environmental Engineering, 142, C4015005, 2015.
33. ACHAL V., PAN X., ZHANG D., FU Q. Bioremediation of $\mathrm{Pb}$-contaminated soil based on microbially induced calcite precipitation. J Microbiol Biotechnol, 22 (2), 244, 2012.

34. KANG C.-H., OH S.J., SHIN Y., HAN S.-H., NAM I.-H., SO J.-S. Bioremediation of lead by ureolytic bacteria isolated from soil at abandoned metal mines in South Korea. Ecological Engineering, 74, 402, 2015. 